\title{
Quality of Assessment Raw Cows' Milk at Different Sampling Points Using Bacteriological Parameters and Other Techniques in Jimma Town, South Western Ethiopia
}

\author{
Asmarech Dolango \\ Konta Special Woreda, Southern Ethiopia \\ Shimelis Argaw \\ Wolaita Sodo Universities, Dawro-Tarcha Campus, P.O.Box 01, Ethiopia \\ Tadele Tolosa and Benti Deresa \\ Jimma University, College of Agriculture and Veterinary medicine, Ethiopia
}

\begin{abstract}
A cross-sectional study was carried out from May 2014 to February 2015 to identify potential sources of raw cows' milk contamination and assess its bacteriological quality, and investigate the bacteriological quality of fresh cows' milk at different sampling points, in Jimma town. A total of 348 milk samples from udder, milking bucket, storage containers and vendors were randomly collected. To determine the bacterial load in raw milk samples, standard plate count test (SPC), coliform counts (CC), somatic cell counts (SCC), and california mastitis test (CMT) were conducted. The overall mean value of total bacterial counts (TBC) and coliform counts (CC) were $6.76 \log _{10}$ $\mathrm{CFU} / \mathrm{ml}$ and $4.57 \log _{10} \mathrm{CFU} / \mathrm{ml}$ respectively. The mean TBC were $5.87 \pm 0.09 \log _{10} \mathrm{CFU} / \mathrm{ml}, 6.14 \pm 0.07 \log _{10}$ $\mathrm{CFU} / \mathrm{ml}, 7.39 \pm 0.13 \log _{10} \mathrm{CFU} / \mathrm{ml}$, and $7.63 \pm 0.06 \log _{10} \mathrm{CFU} / \mathrm{ml}$ at udder, milking bucket, storage container and milk vendor levels respectively. The mean $\mathrm{CC}$ from udder, milking bucket, storage container and vendor were $3.14 \pm 0.09 \log _{10} \mathrm{CFU} / \mathrm{ml}, 4.08 \pm 0.07 \log _{10} \mathrm{CFU} / \mathrm{ml}, 5.07 \pm 0.23 \log _{10} \mathrm{CFU} / \mathrm{ml}$ and $6.00 \pm 0.21 \log _{10} \mathrm{CFU} / \mathrm{ml}$ respectively. The difference in the mean $\mathrm{TBC}$ and $\mathrm{CC}$ at each sampling points were statistically significant $(\mathrm{P}=0.001)$. Among the investigated sampling points, the highest level of contamination in terms of TBC and CC was at vendor level. Factors that contributed to poor quality of milk were unhygienic milking procedures, lack of potable water, dirty milking environment and use of unclean milking and storage containers. According to international standards, TBC, CC and SCC have values above the upper limits set. The results of the current study indicated that the cow milk produced and distributed in the study area can generally be considered as substandard in quality. Therefore, it is important to put in place an improved hygienic practice at all levels in the dairy to improve the quality of cows' milk.
\end{abstract}

Keywords: Coliform Count, Milk Quality, Total Bacterial Count.

DOI: $10.7176 / \mathrm{FSQM} / 104-04$

Publication date: January $31^{\text {st }} 2021$

\section{Introduction}

Livestock farming in general and milk production in particular still play an important socioeconomic role in developing countries (Hamid and Owni, 2007). In Ethiopia, it assures food security for low-income urban and peri-urban population and provides a livelihood fora number of peoples who would otherwise be unable to establish other businesses (Eshetu, 2008; Aseffa, 2010). Although the country has the largest livestock population in Africa, performance in the production of the major food commodities of livestock origin has been poor. This is due to factors such as poor management systems like feeding, housing, watering, and treating of diseased animal, poor marketing access, weak infrastructures, poor genetic improvement, and poor disease control (Befekadu and Birhanu, 2000).

Ethiopia has great potential for dairy development due to its favorable climate for improved, high-yielding animal breeds, and landholdings and integration with crop production as criterion, for livestock production (Mohammed et al., 2004). Milk and milk products are among the most important food products with an animal origin. It is an important source of nutrients to human and animals. It is meant to be the first and the only food for the offspring of mammals as is almost complete food (Pandey and Voskuil, 2011). It is a balanced form of food for building and maintaining the human and animal body as well (Park, 2009).

As milk and milk products play an important role in human nutrition throughout the world, the products must be of high hygienic quality (Soomro et al., 2003). In less developed areas and especially in hot tropics high quality of safe product is most important but not easily accomplished. This is required since milk and milk products are highly susceptible to variety of microorganisms and serves as an excellent culture medium for the growth and multiplication of several microorganisms due to their complex biochemical composition and high water content(Kivaria et al., 2006a). 
The safety of dairy products with respect to food-borne diseases is a great concern around the world. This is especially true in developing countries like Ethiopia, where production of milk and various milk products takes place under unsanitary conditions and poor production practices (Yilma and Faye, 2006; Alganesh et al., 2007; Asaminew and Eyassu, 2011). A commonly used procedure to measure the sanitary quality of milk is to estimate its bacterial content or bacterial load. Different quality tests can be performed through quantifying bacterial population and other microorganisms present in milk and milk products, the major ones being total bacterial count and coliform count (Biruk et al., 2009).

Microorganism may contaminate milk at various stages of procurement, processing and distribution. This contamination could arise from the cow's udder, barn, milk collection equipment, feed, soil, faces, grass, long duration of transportation, various ingredients added to dairy products and dairy farm workers (Wubete, 2004;Kaloreu et al., 2007; Parekh et al.,2008;Garedew et al., 2012). Bacterial contamination of milk not only reduces the nutritional quality but also consumption of such milk threatens health of the society (Nanu et al., 2007). Bacteriological safety of milk continues to be a topic of concern in the dairy industry and public health communities. In general, in order to provide safe and healthy milk products, the Hazard Analysis and Critical Control Points (HACCP) system should be implemented starting from milk collection, through processing and storage. Microbial exposure assessments are critical components of the risk analysis (Oliver, 2009).

The safety and quality of the milk produced by small scale dairy farmers who are the predominant players in the dairy industry has to be guaranteed in order to enable them retain and access convectional markets; considering that consumers were willing to pay more for improved milk safety and quality attributes (Makokha and Fadiga, 2009).The initial microbiological quality of milk can vary substantially based on factors such as the health of the animal, the sanitary condition of the milking environment and the milkers (Biruk et al., 2009). Microbial contamination of milk can therefore originate from within the udder, the exterior of the teats and udder, and from the milk handling and storage equipment (Chambers, 2002; Biruk et al., 2009).

Ethiopia, as a developing country, faces many challenges in producing quality products that are safe for consumption. In the country, there is no standard hygienic condition followed by producers during milk production (Yilma and Faye, 2006). The hygienic conditions are different according to the production system, adapted practices, level of awareness, and availability of resources (Yilma, 2003). Hygienic quality control of milk and milk products in Ethiopia is not usually conducted on routine basis. Apart from this, door-to-door raw milk delivery in the urban and peri-urban areas is commonly practiced with virtually no quality control at all levels (Godefay and Molla, 2000).

In the country, there is a constant challenge to those involved in milk production to prevent or minimize the entry and subsequent growth of microorganisms in milk. This is mainly due to the absence of hygienic practices in dairy farm areas that affect the quality of dairy products (Gonfa et al., 2001).Recent study conducted in different part of Ethiopia, reported that microbial load of the total bacterial counts and coliform counts obtained from the storage containers at farm level and distribution containers upon arrival at selling points were higher than the acceptable limits. This indicates that milk was produced poor hygienically and the equipment's not kept clean (Abebe et al., 2012; Welearegay et al., 2012).Moreover, pervious study conducted yet concerning the microbiological quality of cow milk on dairy farm level in Kersa District, Jimma zone reported that quality and safety of raw cows' milk is compromised by contamination from different sources (Tadesse and Bacha, 2014). But there is no study yet conducted on quality of raw milk along dairy value chain from farm to selling point in Jimma town where there are relatively large number of dairy farms.

In Jimma town, milk and milk products represent an important place in the nutrition of consumers as well as nutrition and income of producers. Although milk and milk products represent an important place, there is paucity of information on quality of raw cow's milk in Jimma town. Therefore, this study was designed to fill this gap with the following general and specific objectives:

\subsection{General objective:}

- To identify potential sources of raw cows' milk contamination and assess its bacteriological quality in Jimma town.

\subsection{The specific objectives:}

- To investigate the quality of fresh cows' milk at different sampling points

- To identify sources of contamination of fresh cows' milk at different sampling points

\section{Materials and methods}

\subsection{Study area}

The study was conducted in Jimma town of Oromia Regional State, South-Western, Ethiopia. Jimma is located at $355 \mathrm{~km}$ South-West of Addis Ababa, the Ethiopian capital, at $7^{\circ} 41^{\prime} \mathrm{N}$ latitude and $36^{\circ} 50^{\prime}$ E longitude and has an altitude of 1704 meters above sea level. The area is characterized by a humid tropical climate of heavy annual 
rainfall that ranges from $1200-2000 \mathrm{~mm}$ per annum. About $80 \%$ of the total annual rainfall is received during rainy season, which extends from May to early September. The mean annual maximum and minimum temperature ranges from $6^{\circ} \mathrm{C}$ and $31^{\circ} \mathrm{C}$ respectively, with an overall average of $18.7^{\circ} \mathrm{C}$ (Alemu et al., 2011). Based on the 2007 Population and Housing Census conducted by the Central Statistical Agency of Ethiopia, this town has a total population of 120,960, of whom 60,824 are men and 60,136 women. Mixed crop-livestock production system is the main form of agriculture in the area. Although the area is mainly known for its coffee production but crop and livestock production are important agricultural activities as well (Tolosa et al., 2013).Milk is produced in small dairy farms established in the city and sold to collection centers and milk retailers and/or to consumers(Tolosa et al., 2013).

\subsection{Study population}

The study animals were dairy cattle's from selected dairy farms in Jimma. The average herd size in study farms were 12 lactating cows, ranges minimum 6 to maximum 16 lactating Holstein-Friesian cross-breed cows managed under indoor and outdoor management system. The estimated daily milk yield was 7 to 9.5 liters/cow/day. The milk collection centers and vendors were used for bulk milk sampling. Milk is delivered to the nearest milk collection centers of their association twice a day. From collection centers, milk sold to the local consumers, cafeterias or selling point. Jimma town has one dairy cooperative, 8 collection centers and 35vendors. The milk collection center owners and the vendors were informed on the purpose of the study prior to sample collection through the dairy co-operative. The time of milk collection from the centers was either during the morning from 8:30 to 9:30am or in late afternoon from 4:00 to $5: 30 \mathrm{pm}$.

\subsection{Study design}

A cross-sectional study was carried out from May 2014 to February 2015. Bulk milk samples were collected from three points of milk suppliers (dairy farms, collection centers and vendors) which were expected to be the major risk areas where contamination can take place as many people may share the pooled product. Raw milk samples were taken from the udder, milking bucket, storage containers at collection center and vendor 3 times from each point.

\subsection{Sampling procedures}

The sampling frame of all dairy farms was obtained from Jimma town dairy producers and marketing cooperative societies. From a total of 52 small holder dairy farms, a recruitment exercise was made to identify a willing dairy farm owners, from these 25 of them were selected randomly. The randomly selected farms that supply their milk to the selected four collection centers were used as sources of samples for this study. Twelve vendors were randomly selected which receives milk mostly from the selected farms and also milk from various production farms. From each farm, three individuals milking cows were randomly selected at randomly selected farms and quarter milk samples were directly collected into sterile screw bottles following the protocol described in National Mastitis Council guidelines (NMC, 1999). Samples were collected from all sampling points at every two month intervals for a period of 6 months. A total of 348 milk samples were collected from the various sampling points (Table 1).

Table 1: Number of samples of raw milk collected from each samplingpoint

\begin{tabular}{llllll}
\hline Sampling period & Udder & Bucket & Collection center & Vendor & Total \\
\hline August-October & 75 & 25 & 4 & 12 & 116 \\
November-December & 75 & 25 & 4 & 12 & 116 \\
January-February & 75 & 25 & 4 & 12 & 116 \\
\hline Total & 225 & 75 & 12 & 36 & 348 \\
\hline
\end{tabular}

\subsection{Study methodology}

\subsubsection{Structured questionnaire survey}

A structured questionnaire (Annex 1) were administered to randomly selected dairy owners or workers (milking personnel and attendants of the farms) to assess associated potential risk factors that might influence the quality of milk. Risk factors include bedding conditions of the barn (categorized as concert, wood shaving and soil), frequency of barn cleaning in a day, type of water (potable water or well water),water used for teat and udder washing purpose (warm potable, cold potable, warm well or cold well water), milk handlers (categorized as washing hand before milking, after milking, before and after milking and didn't do), sanitation of containers, availability of transportation facility, and types of storage facilities (categorized as aluminum, plastic and metal container) for milking, storage and processing of milk. Assessment of local fresh milk production and the marketing chain (from the cow's udder to the selling points) were assessed.

2.5.2. Milk samples collection and transportation

Milk samples were collected from different sampling points: i.e., directly from the teat during milking, milking 
bucket at farm level, storage containers at milk collection center, and vendor. Before sampling of milk, the udder and teats were cleaned and dried using 68\% ethyl alcohol. Then milk was collected after discarding the first 3 streams of milk. Prior to sampling from milking bucket and transport containers, milk samples in the bulk containers were agitated and samples were taken from the top of the bulk milk witha sanitized dipper. Approximately, $25 \mathrm{ml}$ of bulk milk was collected aseptically in sterile plastic containers (Jorgensen et al., 2005). At all levels of sampling, the sampling bottles were capped, labeled with a permanent marker and placed in ice box and transported to the laboratory. The collected samples were handled aseptically in the laboratory to prevent/minimize the contamination. All samples were kept in an ice box and transported to the Mastitis and Milk Quality Laboratory of Jimma University, School of Veterinary Medicine and kept under refrigeration at $4^{\circ} \mathrm{C}$ until processed for microbiological analysis. The milk samples were cultured within 24 hours as described by Quinn et al. (1999).

\subsection{Analysis of milk samples}

2.6.1. Specific gravity

The specific gravity (SG) was used to check the adulteration of milk. A SG of milk was measured byfilling the milk sufficiently in the cylinder. The lactometer was held at the tip, and lowered; gently in to the milk. The lactometer was allowed to float freely until it rest. The lactometer was read at the top of the meniscus. Immediately, the temperature of the milk was checked to be $20^{\circ} \mathrm{C}$. Finally, the $\mathrm{SG}$ was determined using appropriate correction factors (O’Connor, 1995).

2.6.2. California mastitis test

The california mastitis test (CMT) was conducted to screen the presence of subclinical mastitis. A squirt of milk sample was placed in each of four shallow cups in the CMT paddle and an equal amount of the reagent was added in accordance with the manufacturer's guidelines (Delval mastitis test CMT, Poland). A gentle circular motion was applied in a horizontal plane. Positive samples showed gel formation within a few seconds. The result was scored based on the gel formation and categorized as negative if there was no gel formation, or positive if there was gel formation of various degrees. For instance, 0 for negative, $T$ for trace, 1 for weak positive, 2 for distinct positive and 3 for strong positive according to Quinn et al. (1999).

2.6.3. Somatic cell count (SCC)

The somatic cell count (SCC) was used as an indicator of milk quality. The lower the SCC in the milk, the higher the quality of milk and vice versa. Somatic cells are animal body cells present in normal milk in few numbers. It's presence in high levels indicative of intra-mammary infection (IMI). Bulk milk somatic cell count was measured by using Delval direct cell counter (DeLaval, 2004). A100 $\mu 1$ milk samples was placed into a special cassette and mixed a reagent, reacts with the nuclei of somatic cells and optic density was measured. The optical density was recorded as an image, and that image was used to determine the number of somatic density was cells in the milk which visible in Delval cell counter (DCC) within a minute. Then the numbers observed were recorded as the number of somatic cells for a particular sample.

2.6.4. Alcohol test

This is a simple and quick test used on fresh milk to indicate whether it forms curdle or not forms curdle by using the procedures recommended by O' Connor (1994). Briefly, five $\mathrm{ml}$ of milk and $68 \%$ of alcohol (ethanol) were placed in test tubes. The test tubes were inverted several times with the thumb held tightly over the open end of the tube and examined for the formation of curdle particles. If it forms curdle, the milk developed acidity and considered as positive result to alcohol test.

2.6.5. Clot-on-boiling test

The test is simple, quick and cheap, which used to determine whether the milk is likely to clotting, coagulation or precipitation during heat processing by using the procedures recommended (O' Connor, 1994). Five ml of milk was placed in test tubes and then it was placed in a boiling water bath for five minutes. Then, the test tubes were carefully removed from the water bath and examined for the presence of coagulation or precipitation of milk on the side of test tubes. If precipitation was formed, the milk has failed the test and it recorded as positive result to clot on boiling test and it suggesting that milk was sour or acidic, which was not fit for further processing.

2.6.6. Determination of milk quality

2.6.6.1. Standard plate count (SPC)

Standard plate count (SPC) method was used to assess the number of viable bacterial load in milk and graded in to different categories according to its bacterial content. Standard plate count (total bacterial count) was made by adding $1 \mathrm{ml}$ of milk sample with sterile disposable pipette into sterile test tube having $9 \mathrm{ml}$ buffered peptone water. After thoroughly mixing, the sample was serial tenfold diluted from $10^{-1}$ to $10^{-6}$ and duplicate samples $(1 \mathrm{ml})$ were pour plated using 12-15 ml melted standard plate count agar (Oxoid, UK) solution and mixed thoroughly. The plated sample was allowed to solidify and then incubated at $37^{\circ} \mathrm{C}$ for $24-48$ hours. Quantification of colonies was done following incubation, plates exhibiting 25-250 colonies were counted for TBC using colony counter. The average number of colonies in a particular dilution was multiplied by the dilution factor to obtain the TBC. The 
counts for each plate were expressed as the colony forming units per $\mathrm{ml}(\mathrm{CFU} / \mathrm{ml})$ of samplesof the standard procedures, according to recommendation of American Public Health Association (1992).

2.6.6.2. Coliform count (CC)

Coliform count (CC) was performed by adding $1 \mathrm{ml}$ of milk sample into sterile test tube having $9 \mathrm{ml}$ buffered peptone water. After mixing the samples were serially diluted up to $10^{-1}$ to $10^{-6}$ and duplicated samples $(1 \mathrm{ml})$ were plated using 12-15 $\mathrm{ml}$ the selective and differential medium Violet Red Bile Agar (VRBA) (Oxid, UK). After thoroughly mixing, the plated sample was allowed to solidify and then incubated at $37^{\circ} \mathrm{C}$ for $24-48$ hours. After incubation, plates exhibiting 10-100 colonies counted, which were dark red characteristics for CC using colony counter and the total number of colonies found was multiplied by the dilution factor according to standard procedures by American Public Health Association (1992).

After counting and recording bacterial colonies for both counts (TBC and $\mathrm{CC}$ ) on selected plates, the number of bacteria in 1 milliliter of milk was calculated (APHA, 1992).

$\mathrm{N}=\sum$ colonies

$[(\mathrm{n} 1 \times 1)+(0.1 \times n 2)] \times d$

Where: $\mathrm{N}=$ number of colonies per milliliter of milk,

$\Sigma \mathrm{C}=$ sum of colonies on plates counted,

$\mathrm{n} 1=$ number of plates on lower dilution counted,

$\mathrm{n} 2=$ number of plates in next higher dilution counted and

$\mathrm{d}=$ dilution factor of the lower dilution counted

\subsection{Data management and analysis}

Microsoft Excel spread sheet was used for raw data base establishment and management. Descriptive statistics such as minimum, maximum, mean, percentage, and frequency distributions were used to compute the data by using Statistical Package for Social Science(SPSS, 2010) version 16.0(SPSS Inc. Chicago). The $\log _{10}$ transformation of bacterial count was done before the analysis of bacterial counts. The analysis of variances test (ANOVA) was used to show the association between mean of bacterial counts at different sampling points, and the effect of sources on bacterial counts. The significance of differences $(p<0.05)$ of the mean microbial count was evaluated with one way ANOVA. Relationship between different factors for microbial contamination in raw milk was computed against TBC and CC. For all analysis, statistical significance was established at $95 \%$ confidence interval and $\mathrm{p}<0.05$.

\section{RESULTS}

3.1. Description of milk production system

All farms included in this study had ranged from 6 to 16 cross-breeds (Holstein Friesian with indigenous) lactating dairy cows. Wheat bran, hay, straw and grass were some of the feed items in the farms. The selling time of milk was two times a day (morning and afternoon).

None of the collection centers used alcohol test for milk quality checking. Cooling system was not used in both collection centers and milk vendors. Milk was stored in plastic containers until distributed or sold to the local customers, shops or cafeterias. All the milk collection centers were located along roadsides that could likely expose the milk to dust contamination created by moving vehicles. Almost all vendors were using plastic containers for milk storage and processing purpose.

Milking was done in the barn by hand in all farms by male workers and none of the farms had cooling systems and transportation facility. Twelve percent and $60 \%$ of the farms were used metal and plastic containers for milking, storage and processing, respectively. The milk passes through different plastic containers before reaching to the consumers. Most dairy farms did not use sieves. In almost all the farms, the floor of the house, cleanliness of the milking house, milking personnel, milking and storage containers, udder and teat preparation and water used for these purposes were poor. Milkers were not seen washing of hands between cows in all farms. Most farms $(84 \%)$ did not use teat dip and towel but very few of the farms use a common towel. Only (8\%) and (16\%) of farms were used warm well water and warm potable water for udder washing purpose respectively. In addition, most farms were milking in a cow barn (Table 2). 
Table 2: Hygienic practices of dairy farms in Jimma

\begin{tabular}{lll}
\hline Farm practices & Numbers of farms & Percentage (\%) \\
\hline Frequency of barn cleaning & & \\
$\quad 1-2$ times per day & 19 & 76 \\
$\quad$ 3-4 times per day & 6 & 24 \\
Water used for washing teat and udder & & \\
Warm potable water & 4 & 8 \\
Cold potable water & 2 & 8 \\
Warm well water & 2 & 68 \\
Cold well water & 17 & \\
Use teat dip and towel to clean teat before milking & 4 & 16 \\
Yes & 21 & 84 \\
No & & \\
Dry hand before milking & 4 & 16 \\
Yes & 21 & 84 \\
No & & \\
Cows milking takes place & 23 & 92 \\
In barn & 2 & 8 \\
In milking room & & \\
Types of storage container & 7 & 28 \\
Aluminum & 15 & 60 \\
Plastic & 3 & 12 \\
Metal & & \\
Types of bedding in farms & 4 & 20 \\
Concerte & 13 & 48 \\
Woody shaving & 8 & 32 \\
Soil & & \\
Time of washing hands & 6 & 24 \\
Before milking & 12 & 48 \\
After milking & 3 & 12 \\
Before and after milking & 4 & \\
Didnot wash at all & & \\
\hline
\end{tabular}

\subsection{Milk analysis}

4.2.1. Specific gravity, alcohol and boiling tests

The majority $(95 \%)$ of the milk samples in this study had specific gravity values between 1.027 and 1.031 which was acceptable range. Only (5\%) of the milk samples had specific gravity below 1.025 which was an indicative of adulteration. All milk samples at collection centers and at the same time at vendors level were found to be positive to alcohol and boiling tests.

4.2.2. California mastitis test (CMT)

Ninety two percent of milk samples $(\mathrm{n}=25)$ examined were positive to CMT. Accordingly, $1(4 \%)$ trace, $3(12 \%)$ weak, $4(16 \%)$ distinct and $15(60 \%)$ of samples were strongly positive for CMT which was indicative of mastitis. 4.2.3 .Milk quality indicator tests

4.2.3.1. Total bacterial counts and coliform counts

The overall mean total bacterial count (TBC) and coliform count (CC)of cow's milk were $6.76 \log _{10} \mathrm{CFU} / \mathrm{ml}$ and $4.57 \log _{10} \mathrm{CFU} / \mathrm{ml}$ respectively. The total viable counts varied from 0 to $7.93 \log _{10} \mathrm{CFU} / \mathrm{ml}$ at udder, 3.57 to 7.80 $\log _{10} \mathrm{CFU} / \mathrm{ml}$ at milking bucket, 6.87 to $7.83 \log _{10} \mathrm{CFU} / \mathrm{ml}$ storage containers at collection centerand 5.61 to $7.83 \log _{10} \mathrm{CFU} / \mathrm{ml}$ at vendor level. Results of analysis of variance indicated that there were statistically significant differences $(\mathrm{p}=0.001)$ in total bacterial counts of milk at udder, milking bucket, storage containers at collection center and vendor. The mean \pm standard error of coliform counts in udder, milking bucket, collection center and vendor were $3.14 \pm 0.09 \log _{10} \mathrm{CFU} / \mathrm{ml}, 4.08 \pm 0.07 \log _{10} \mathrm{CFU} / \mathrm{ml}, 5.07 \pm 0.23 \log _{10} \mathrm{CFU} / \mathrm{ml}$ and $6.00 \pm 0.21 \log _{10}$ $\mathrm{CFU} / \mathrm{ml}$ respectively. There was an increasing trend of coliform counts as the milk passed through udder, milking bucket, collection centers and vendors. Results of analysis of variance indicated that there were statistically significant difference $(\mathrm{p}=0.001)$ in coliform counts between the sampling points (Table 3 ). 
Table 3: Minimum, maximum and mean ( \pm standard error) of total bacterial counts $(\mathrm{TBC})$ and coliform counts (CC) of milk samples $\left(\log _{10} \mathrm{CFU} / \mathrm{ml}\right)$ in the four sampling points

\begin{tabular}{lllllll}
\hline Type of counts & Samp.pt & No. & Minimum & Maximum & Mean $( \pm$ S.E $)$ & P-value \\
\hline TBC & & & & & & 0.001 \\
& Udder & 225 & 0 & 7.93 & $5.87(0.09)$ & \\
Bucket & 75 & 3.57 & 7.80 & $6.14(0.07)$ & $7.39(0.13)$ \\
& C.center & 12 & 6.64 & 7.83 & $7.63(0.06)$ & \\
& Vendor & 36 & 5.61 & 7.83 & $6.76(0.06)$ & 0.001 \\
\hline CC & Total & 348 & 3.57 & 7.82 & & \\
& & & & & & \\
& Udder & 225 & 0 & $5.14(0.09)$ & $5.08(0.07)$ & \\
& Bucket & 75 & 0 & 5.71 & $6.07(0.23)$ & \\
& C.center & 12 & 0 & 6.65 & $6.00(0.21)$ & \\
\hline
\end{tabular}

TBC: Total bacterial count, CC: Coliform count, C. center: Collection center, S.E: Standard error, $\log _{10} \mathrm{CFU} / \mathrm{ml}$ : Logarithm in base 10 of colony forming unit per ml, No.: number of raw milk samples, Samp.pt: sampling points

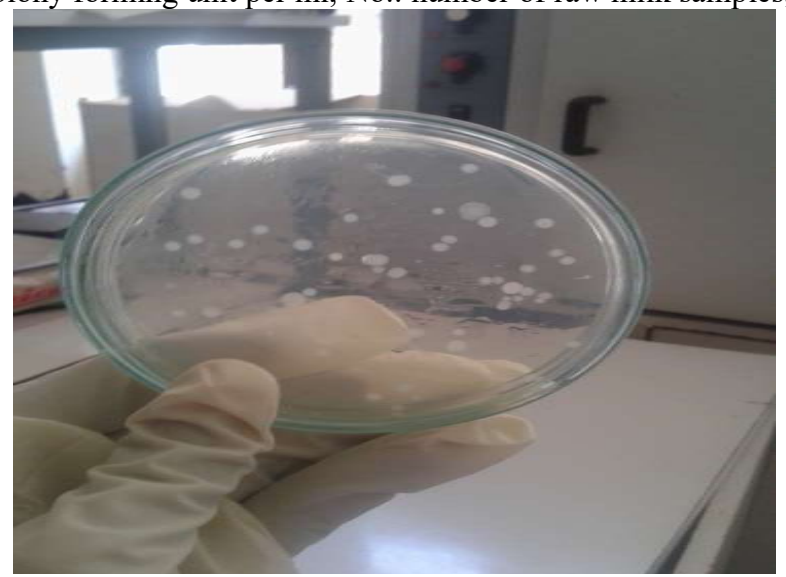

Figure 3: Shows colonies of total bacterial count in PCA media

The mean \pm standard error of total bacterial counts and coliform counts (expressed in $\log _{10} \mathrm{CFU} / \mathrm{ml}$ ) of raw milk sampled from the three sources were shown (Table 4). Milk samples collected from vendors were higher bacterial load (TBC and $\mathrm{CC}$ ) than milk samples collected from dairy farms. Results of analysis of variance indicated that there were statistically significant differences in mean $\mathrm{TBC}$ and $\mathrm{CC}(\mathrm{p}=0.001)$ between the three sources of sampling.

Table 4: Summary of mean ( \pm standard error) for TBC and CC (expressed in $\left.\log _{10} \mathrm{CFU} / \mathrm{ml}\right)$ of bulk milk samples based on the source of samples excluding udder

\begin{tabular}{lllll}
\hline Type of counts & Sources & Mean $( \pm$ S.E) & $95 \%$ CI for mean & P-value \\
\hline TBC & & & & 0.001 \\
& Farm & $6.14(0.07)$ & $(5.99,6.27)$ & \\
C. center & $7.39(0.13)$ & $(7.12,7.67)$ & \\
& Vendor & $7.63(0.06)$ & $(7.49,7.76)$ & 0.001 \\
CC & & & \\
& Farm & $4.08(0.07)$ & $(3.93,4.21)$ & \\
& C. center & $5.07(0.23)$ & $(4.56,5.60)$ & \\
& Vendor & $6.00(0.21)$ & $(5.58,6.42)$ & \\
\hline
\end{tabular}

TBC: Total bacterial count, CC: Coliform count, \pm S.E: standard error, CI: Confidence interval 


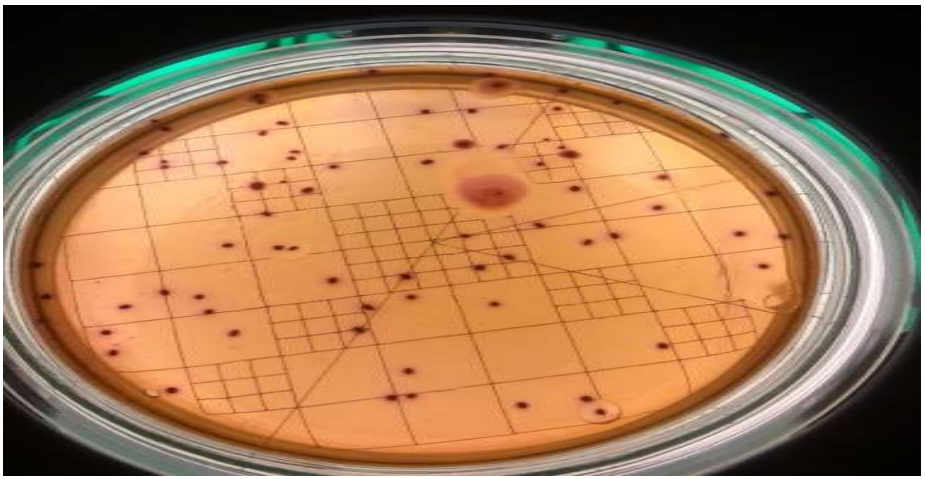

Figure 4: Shows coliform counts under colony counter

Accordingly our finding, the mean TBC was increased by $\left(1.25 \log _{10} \mathrm{CFU} / \mathrm{ml}\right)$ from milking bucket (farm) to storage containers of milk samples taken at collection center. Similarly, mean TBC was increased by (1.49 $\log _{10} \mathrm{CFU} / \mathrm{ml}$ ) from point of milking bucket to vendor. The mean difference of CCbetween the groups of critical points of farm to vendor was $\left(0.93 \log _{10} \mathrm{CFU} / \mathrm{ml}\right)($ Table 5$)$.

Table 5: Comparisons of mean ( \pm standard error) $\mathrm{TBC}$ and $\mathrm{CC}\left(\log _{10} \mathrm{CFU} / \mathrm{ml}\right)$ to see themean difference between the sources

\begin{tabular}{|c|c|c|c|c|c|c|}
\hline & Source & Source & Mean difference & $(+$ S.E $)$ & $95 \% \mathrm{CI}$ & P-value \\
\hline \multicolumn{7}{|l|}{ TBC } \\
\hline & \multirow[t]{2}{*}{ Farm } & Vendor & 1.49 & $(0.81)$ & $(1.93,1.05)$ & 0.001 \\
\hline & & C.center & 1.25 & $(0.31)$ & $(1.98,0.52)$ & 0.001 \\
\hline & \multirow[t]{2}{*}{ Vendor } & Farm & 1.49 & $(0.18)$ & $(1.05,1.94)$ & 0.001 \\
\hline & & C.center & 0.24 & $(0.35)$ & $(0.59,1.06)$ & 0.77 \\
\hline & \multirow[t]{2}{*}{ C.center } & Farm & 1.25 & $(0.31)$ & $(0.52,1.98)$ & 0.001 \\
\hline & & Vendor & 0.24 & $(0.35)$ & $(1.06,0.59)$ & 0.77 \\
\hline \multicolumn{7}{|c|}{$(1.00,0.07)$} \\
\hline & \multirow[t]{2}{*}{ Farm } & Vendor & 0.93 & $(0.20)$ & $(2.40,1.45)$ & 0.001 \\
\hline & & C.center & 0.99 & $(0.33)$ & $(1.78,0.21)$ & 0.001 \\
\hline & \multirow[t]{2}{*}{ Vendor } & Farm & 1.93 & $(0.20)$ & $(1.45,2.40)$ & 0.001 \\
\hline & & C.center & 0.93 & $(0.37)$ & $(0.04,1.81)$ & 0.03 \\
\hline & \multirow[t]{2}{*}{ C.center } & Farm & 0.99 & $(0.33)$ & $(0.21,1.78)$ & 0.001 \\
\hline & & Vendor & 0.93 & $(0.37)$ & $(1.81,0.04)$ & 0.03 \\
\hline
\end{tabular}

One -Way ANOVA test(Post hoc test), mean difference is significant at 0.05 levels

The mean \pm standard error for total bacterial counts and coliform counts $\left(\log _{10} \mathrm{CFU} / \mathrm{ml}\right)$ at three different periods of sampling were presented (Table 6). The difference in mean total bacterial counts of milk at the udder level and storage containers at the collection center were statistically significance difference $(\mathrm{p}<0.05)$ among the different sampling periods.

Table 6: Mean ( \pm standard error) of TBC and CC of raw milk at different sampling points and periods of sampling $\underline{\left(\log _{10} \mathrm{CFU} / \mathrm{ml}\right)}$

\begin{tabular}{llllll}
\hline Type of counts & Sampling point & August-October & November-December & January-February & P-value \\
\hline TBC & Udder & $5.72(0.17)$ & $5.83(0.14)$ & $6.37(0.13)$ & 0.01 \\
& Bucket & $6.50(0.12)$ & $6.34(0.11)$ & $6.32(0.10)$ & 0.99 \\
& C.center & $7.70(0.06)$ & $7.59(0.07)$ & $6.87(0.20)$ & 0.03 \\
& Vendor & $7.68(0.10)$ & $7.53(0.18)$ & $7.72(0.04)$ & 0.51 \\
\hline CC & Udder & $3.09(0.16)$ & $3.24(0.15)$ & $3.11(0.09)$ & 0.85 \\
& Bucket & $4.39(0.13)$ & $4.47(0.13)$ & $4.20(0.12)$ & 0.38 \\
& C. center & $4.91(0.62)$ & $5.00(0.00)$ & $5.31(0.45)$ & 0.81 \\
& Vendor & $6.18(0.21)$ & $5.68(0.55)$ & $6.15(0.19)$ & 0.56 \\
\hline
\end{tabular}

TBC: total bacterial count, CC: coliform counts, C. center: collection center

Fifty six percent of raw milk samples from udder, $65.4 \%$ of bulk milk from milking bucket, $100 \%$ of bulk milk from storage containers at collection center and from vendors had counts above $4 \times 10^{5} \mathrm{CFU} / \mathrm{ml}$ which was higher than the international standard set for acceptable total bacterial counts and were graded as poor quality. In the case of coliform count, $80.5 \%$ from udder, $96 \%$ from milking bucket, $100 \%$ from storage containers at collection center and from vendors had counts greater than $1.50 \times 10^{2} \mathrm{CFU} / \mathrm{ml}$ which was regarded as poor quality as per international standard(EU) set for acceptable coliform counts(Table 7). 
Table7: Quality of milk samples categorized on the basis of bacterial loadunder three grades (quality) (\%) based on international standard set

\begin{tabular}{llllll}
\hline Type of counts & Point of sampling & No. & Very good quality & Fairy quality & Poor quality \\
\hline TBC & Udder & 225 & $46(20.5)$ & $52(23)$ & $127(56.5)$ \\
& Bucket & 75 & $10(13.3)$ & $16(21.3)$ & $49(65.4)$ \\
& C.center & 12 & $0(0)$ & $0(0)$ & $12(100)$ \\
& Vendor & 36 & $0(0)$ & $0(0)$ & $36(100)$ \\
\hline CC & Udder & 225 & $21(9.3)$ & $23(10.2)$ & $181(80.5)$ \\
& Bucket & 75 & $2(2.7)$ & $1(1.3)$ & $72(96)$ \\
& C.center & 12 & $0(0)$ & $0(0)$ & $12(100)$ \\
& Vendor & 36 & $0(0)$ & $0(0)$ & $36(100)$ \\
\hline
\end{tabular}

Recommended values (EU), TBC $=$ Very good quality $=<1 \times 10^{5} \mathrm{CFU} / \mathrm{ml}$, Fair quality $=1 \times 10^{5}-4 \times 10^{5} \mathrm{CFU} / \mathrm{ml}$, Poor quality $=>4 \times 10^{5} \mathrm{CFU} / \mathrm{ml}, \mathrm{CC}=$ Very good quality $=<50 \mathrm{CFU} / \mathrm{ml}$, Fair quality $=50-150 \mathrm{CFU} / \mathrm{ml}$, Poor quality $=>1.50 \times 10^{2} \mathrm{CFU} / \mathrm{ml}$, No.: number of raw milk samples

4.2.3.2. Somatic cell counts

The numbers of milk samples falling into different categories of SCC were presented (Table 10). Thirty seven percent of milk samples had somatic cell counts between $4 \times 10^{5}-75 \times 10^{4}$ cells $/ \mathrm{ml}$ which was higher than the European standard set for acceptable range (group 3). Only (2.7\%) of samples showed cell counts between $2 \times 10^{5}$ and $4 \times 10^{5}$ cells $/ \mathrm{ml}$ (group 2) which was acceptable level for human consumption according to the EU (Table 8 ). Table 8: Somatic cell counts in raw milk samples (cells $/ \mathrm{ml}$ ) categorized based on EU standard set

\begin{tabular}{|c|c|}
\hline \multicolumn{2}{|c|}{ Cells/mlSCC distribution from udder samples $(\%)$ Farms $(n=25)(\%)$} \\
\hline Group $1<2 \times 10^{5} 0(0)$ & $0(0)$ \\
\hline Group $2 \quad 2 \times 10^{5}-4 \times 10^{5} 2(2.7)$ & $2(8)$ \\
\hline Group $34 \times 10^{5}-7.5 \times 10^{5} 28(37.3)$ & $9(36)$ \\
\hline Group $4 \quad>7.5 \times 10^{5} 45(60)$ & $14(56)$ \\
\hline
\end{tabular}

4.2.3.3. Risk factors associated with bacterial counts

In our study, milk samples collected from dairy farms thatused well water for washing purpose had higher mean TBC (6.26 $\left.\log _{10} \mathrm{CFU} / \mathrm{ml}\right)$ than farmsthose using potable water $\left(5.53 \log _{10} \mathrm{CFU} / \mathrm{ml}\right)$. The mean TBC was associated with source of water and the difference was statisticallysignificant $(\mathrm{p}<0.05)$. The influence of type of bedding, place of milking, udder cleaning practice and time of washing hands on TBC was statistically significant $(\mathrm{p}<0.05)$ (Table 9).

Table 9:Variation in mean TBCat udder level (Mean \pm S.E) $\left(\log _{10} \mathrm{CFU} / \mathrm{ml}\right)$ among raw milk samples collected under different variables

\begin{tabular}{lllll}
\hline Variables & No. & Mean $( \pm$ S.E $)$ & $95 \%$ of CI for Mean & P-value \\
\hline Source of water & & & & 0.001 \\
Potable water & 93 & $5.53(0.14)$ & $(5.24,5.82)$ & \\
Well water & 132 & $6.26(0.10)$ & $(6.03,6.44)$ & 0.01 \\
Time of washing hands & & & & \\
Before milking & 101 & $6.06(0.14)$ & $(5.77,6.35)$ & \\
After milking & 67 & $6.11(0.13)$ & $(5.84,6.35)$ & \\
Before and after milking & 24 & $5.33(0.22)$ & $(4.87,579)$ & \\
Didn't wash at all & 33 & $5.67(0.16)$ & $(5.33,6.10)$ & \\
Water used for teat and udder washing & & & \\
Warm potable water & 36 & $5.52(0.23)$ & $(5.05,5.99)$ & \\
Cold potable water & 21 & $6.66(0.26)$ & $(6.11,7.20)$ & \\
Warm well water & 15 & $4.87(0.14)$ & $(4.56,5.18)$ & \\
Cold well water & 153 & $6.07(0.11)$ & $(5.83,6.30)$ & \\
Type of bedding in farm & & & \\
Wood shaving & 110 & $6.18(0.11)$ & $(5.94,6.42)$ & \\
Soil & 70 & $5.86(0.18)$ & $(5.48,6.22)$ & \\
Concert & 45 & $5.29(0.15)$ & $(4.97,5.61)$ & \\
\hline
\end{tabular}

\pm S.E: standard error, CI: confidence interval, No.: number of raw milk samples

Milk samples taken from dairy farms that were washed their hand before milking, and before and after milking had lower mean TBC (6.02and $\left.5.86 \log _{10} \mathrm{CFU} / \mathrm{ml}\right)$ than those samples that were washed hand after milking and did not do $\left(6.36\right.$ and $\left.6.64 \log _{10} \mathrm{CFU} / \mathrm{ml}\right)$. The result also revealed that there was a statistically significant variation for TBC between samples collected from dairy farms those milkers dry hands by towel before milking and farms those didn't do by which milk samples from dairy farms those milkers dry hands by towel before milking had lower bacterial count $\left(5.89 \log _{10} \mathrm{CFU} / \mathrm{ml}\right)$ than those from farms didn't do $\left(6.27 \log _{10} \mathrm{CFU} / \mathrm{ml}\right)($ Table 10$)$. 
Table 10: Variation in mean TBC at farm level (Mean \pm S.E) $\left(\log _{10} \mathrm{CFU} / \mathrm{ml}\right)$ among bulk milk samples collected under different variables

\begin{tabular}{|c|c|c|c|c|}
\hline Variables & No. & Mean $( \pm$ S.E $)$ & $95 \%$ CI for mean & P-value \\
\hline Milk storage containers & & & & 0.03 \\
\hline Aluminum container & 21 & $5.92(0.12)$ & $(5.67,6.17)$ & \\
\hline Plastic container & 45 & $6.45(0.09)$ & $(6.12,6.50)$ & \\
\hline Metal container & 9 & $6.00(0.20)$ & $(5.57,6.38)$ & \\
\hline Source of water & & & & 0.03 \\
\hline Potable water & 26 & $6.02(0.08)$ & $(5.58,6.20)$ & \\
\hline Well water & 49 & $6.35(0.11)$ & $(6.11,6.59)$ & \\
\hline Time of washing hand & & & & 0.04 \\
\hline Before milking & 39 & $6.02(0.10)$ & $(5.82,6.22)$ & \\
\hline After milking & 18 & $6.36(0.16)$ & $(5.91,6.56)$ & \\
\hline Before and after milking & 8 & $5.86(0.20)$ & $(5.44,6.28)$ & \\
\hline Didn't wash at all & 10 & $6.64(0.16)$ & $(6.29,6.99)$ & \\
\hline Type of bedding in farm & & & & 0.04 \\
\hline Wood shaving & 38 & $6.50(0.10)$ & $(6.09,6.50)$ & \\
\hline Soil & 23 & $6.10(0.17)$ & $(5.68,6.39)$ & \\
\hline Concert & 14 & $5.92(0.11)$ & $(5.68,6.15)$ & \\
\hline Hand dry by towel before milking & & & & 0.04 \\
\hline Yes & 13 & $5.89(0.14)$ & $(5.62,6.14)$ & \\
\hline No & 62 & $6.27(0.08)$ & $(6.05,6.38)$ & \\
\hline
\end{tabular}

No.: number of raw milk samples, CI: confidence interval

In this study, samples from dairy farms that used well water had higher mean CC $\left(3.46 \log _{10} \mathrm{CFU} / \mathrm{ml}\right)$ compared to those using potable water $\left(2.94 \log _{10} \mathrm{CFU} / \mathrm{ml}\right)$. In addition, milk samples taken from farms where milking takes place in barn had higher bacterial load $\left(3.19 \log _{10} \mathrm{CFU} / \mathrm{ml}\right)$ than those milked in milking room (2.35 $\left.\log _{10} \mathrm{CFU} / \mathrm{ml}\right)$. The difference in mean CC of milk at udder level was statistically significant in all of the assessed variables $(\mathrm{p}<0.05)($ Table 11$)$.

Table11: Variations in mean CC at udder level (Mean \pm S.E) $\left(\log _{10} \mathrm{CFU} / \mathrm{ml}\right)$ among raw milk samples collected under different variables

\begin{tabular}{lllll}
\hline Variables & No. & Mean $( \pm$ S.E $)$ & $95 \%$ CI for mean & P- value \\
\hline $\begin{array}{l}\text { Source of water } \\
\text { Potable water }\end{array}$ & 93 & $2.94(0.14)$ & $(2.65,3.23)$ & 0.04 \\
Well water & 132 & $3.46(0.12)$ & $(3.05,3.55)$ & \\
Place of milking & & & & \\
In milking room & 18 & $2.35(0.34)$ & $(1.61,3.09)$ & \\
In barn & 207 & $3.19(0.09)$ & $(3.00,3.38)$ & \\
Time of hand washing & & & & \\
Before milking & 101 & $3.10(0.27)$ & $(2.53,3.65)$ & \\
After milking & 67 & $3.31(0.18)$ & $(2.94,3.66)$ & \\
Before and after milking & 24 & $2.35(0.28)$ & $(2.53,3.69)$ & \\
Didn't wash at all & 33 & $3.15(0.13)$ & $(2.89,3.41)$ & \\
\hline
\end{tabular}

\section{DISCUSSION}

The safety of dairy products with respect to food-borne diseases is a great concern around the world in general and in developing countries like Ethiopia in particular, where the production of milk and milk products take place under unsanitary conditions and poor production practices (Wubete, 2004; Yilma and Faye, 2006).

Proper udder preparation and teats antiseptic is important to reduce the contamination that could arise from direct contact with the ground, urine, dung and feed refusals while resting (Ruegg, 2003). In this study, most of the farms $(84 \%)$ did not use teat dip and towel to clean teat and udder before milking. However, few dairy owners used a common towel for all cows in share to dry the udders. This reuse of towel for cleaning may recontaminate the udder. In addition, most dairy cow owner's (68\%) in the present study cleaned their cows' teat and udder only with cold well water and did not perform the cleaning sufficiently and hence could serve as a major cause of milk contamination. Similar findings were also reported (Galton, 1986; Gonfa et al., 2001) that insufficiently cleaning the udder before milking and lack of other pre-milking hygienic preparations plays an important role in the contamination of milk during milking.

Containers used for milking, storage and processing determine the quality of milk and milk products (Bonfoh, 2003). The result identified in our study was very much related to the type and cleanliness of the milk containers used for milking, storage and transportation. Majority (60\%) of the farms in the current study used for storage and 
transportation purpose were plastic container and washing the bottom and inner corners of this material was difficult and thus may lead to sticking of milk residues. This end up rapidly builds up of microorganism consequently contaminating the milk on subsequent uses. Similar observations were also reported in Ethiopia (Abebe et al., 2012) and other countries (Kivaria et al., 2006a; Bukuku, 2013; Shija, 2013) in which high microbial load in milk were correlated with narrow necked plastic containers used in handling of milk. Also in the current study, the milk vendors transfer small quantities of milks in to big container while receiving milk, agrees with Bonfoh et al. (2003) who reported handling of small quantities of milk with a big container (small milk volume to container ratio) contributes to high level of contamination of milk.

The acceptable limit for total bacterial counts(TBC), coliform counts (CC) and somatic cell counts (SCC)for raw milk in developed world (American and European community member states: EU) are between $2 \times 10^{5}$ and $4 \times 10^{5} \mathrm{CFU} / \mathrm{ml}, 1.50 \times 10^{2} \mathrm{CFU} / \mathrm{ml}$, and $<2 \times 10^{5}$ and between $2 \times 10^{5}$ and $4 \times 10^{5} \mathrm{cells} / \mathrm{ml}$ respectively (APHA, 1992; Hillerton et al., 2004). However, (56.5\%) of the milk samples from udder, $(65.4 \%)$ from the bucket at farm level, and (100\%) from storage containers at collection center and vendor in this study had TBC greater than $4 \mathrm{x}$ $10^{5} \mathrm{CFU} / \mathrm{m}$. While the $\mathrm{CC},(80.5 \%)$ of the raw milk samples from udder, $(96 \%)$ from bucket and $(100 \%)$ from storage containers at collection center and transportation containers upon arrival at selling point (vendor) had counts greater than the acceptable limit for quality and graded as poor quality which was not fit for further processing. Ninety seven percent of the milk samples from the farms had SCC greater than the acceptable limit and graded as poor quality. In general milk presented for the consumer in Jimma town had a high bacterial loads and cell counts. This indicative of the prevailing substandard milk handling practices (Biruk et al., 2009). This agrees with the work of Fatineet al. (2012),Reda et al. (2014) and Mesfine et al. (2015) in Ethiopia and elsewhere, Al-Tahiri (2005) in Jordan,Kivaria et al. (2006a) in Tanzania, and Parekh and Subhash (2008) in India, who reported higher bacterial counts that exceeds the acceptable limit.

The overall mean total bacterial count (TBC) $\left(6.76 \log _{10} \mathrm{CFU} / \mathrm{ml}\right)$ of cow's milk in the study area was higher than the acceptable value by American Public Health Association (1992) which is (5.3-5.6 $\left.\log _{10} \mathrm{CFU} / \mathrm{ml}\right)$,and the current result was in agreement with the findings of the previous works in Ethiopia by Ashenafi and Beyene (1994) (6.65 $\left.\log _{10} \mathrm{CFU} / \mathrm{ml}\right)$,Yilma and Fay (2006) (6.97 and $\left.6.81 \log _{10} \mathrm{CFU} / \mathrm{ml}\right)$, Debebe (2010) $\left(6.98 \log _{10} \mathrm{CFU} / \mathrm{ml}\right)$, Yigrem and Welearegay(2015)(6.79 $\left.\log _{10} \mathrm{CFU} / \mathrm{ml}\right)$ from Hawassa, and Mesfine et al. (2015)(6.76 $\left.\log _{10} \mathrm{CFU} / \mathrm{ml}\right)$ in Dire Dawa. Apart from Ethiopia, the current result was comparable to the findings ofRai and Dawvedi (1990) $6.68 \log _{10} \mathrm{CFU} / \mathrm{ml}$ from India, and AbdElrahman (2009) (6.63 $\left.\log _{10} \mathrm{CFU} / \mathrm{ml}\right)$ from Sudan. However, this finding was higher than the previous works in Ethiopia by Fekadu (1994) (3-5.7 $\log _{10} \mathrm{CFU} / \mathrm{ml}$ )from Adeno, Gulgula and Dongora districts of Southern Ethiopia, Asrat (2010) (6.36 $\log _{10}$ CFU/ml) from Wolaytazone and Welearegay et al.(2012) (4.57 $\left.\log _{10} \mathrm{CFU} / \mathrm{ml}\right)$ from Hawassa, and also higher than the previous works in other countries by Ombui et al. (1995) $\left(5 \log _{10} \mathrm{CFU} / \mathrm{ml}\right)$ from Kenya, Esther et al. (2004) $\left(6 \log _{10} \mathrm{CFU} / \mathrm{ml}\right)$ from Botswana and Stulova et al. (2010) (4.43 $\left.\log _{10} \mathrm{CFU} / \mathrm{ml}\right)$ from Estonia. Possible reasons for the high total bacterial counts could be poor udder preparation, unhygienic milking procedures and inferior quality of water used for cleaning equipments, dirty milking environment, and time elapsed since milking for storing and transporting without utilization of refrigerator.

In this study, the mean TBC (7.39 $\left.\log _{10} \mathrm{CFU} / \mathrm{ml}\right)$ and $\mathrm{CC}\left(5.07 \log _{10} \mathrm{CFU} / \mathrm{ml}\right)$ of raw milk fromstorage containers at collection center was comparable with findings ofWubete (2004) $\left(7.32 \log _{10} \mathrm{CFU} / \mathrm{ml}\right)$ from DebreZeit, Alganesh et al. (2007) (7.3 $\left.\log _{10} \mathrm{CFU} / \mathrm{ml}\right)$ from Wollega,Tassew and Seifu (2011) $\left(7.58 \log _{10} \mathrm{CFU} / \mathrm{ml}\right)$ from Bahir Dar Zuria and Mecha district, Bonfoh (2003) ( $7 \log _{10}$ CFU/ml) from Mali and Esther et al. (2004) (7.47 $\log _{10} \mathrm{CFU} / \mathrm{ml}$ ) from Botswana. However, the current result of TBC was higher than the reports of Fekadu (1994) (6 $\left.\log _{10} \mathrm{CFU} / \mathrm{ml}\right)$ from southern region, Godefay and Molla(2000) (4.04 $\log _{10} \mathrm{CFU} / \mathrm{mland}\left(6.60 \log _{10} \mathrm{CFU} / \mathrm{ml}\right)$ around Addis Ababa, and Aberra (2010) (6.89 $\log _{10} \mathrm{CFU} / \mathrm{ml}$ ) in and around Addis Ababa. The mean CC of raw milk, in this study, was higher than the reports of Godefay and Molla (2000) (4.11 to $\left.4.85 \log _{10} \mathrm{CFU} / \mathrm{ml}\right) \mathrm{from}$ Addis Ababa, and Alganesh et al. (2007) (4.46 $\log _{10} \mathrm{CFU} / \mathrm{ml}$ ) from East Wallega, Ethiopia. The higher counts imply the sanitary conditions in which milk has been produced and handled are substandard.

The mean TBC ( $\left.7.63 \log _{10} \mathrm{CFU} / \mathrm{ml}\right)$ and $\mathrm{CC}\left(6.0 \log _{10} \mathrm{CFU} / \mathrm{ml}\right)$ of raw milk at vendor level obtained in this study was inline with previous findings by Haile (1989) (7.24-7.87 $\left.\log _{10} \mathrm{CFU} / \mathrm{ml}\right)$, DeGraaf et al. (1997) (7.58 $\left.\log _{10} \mathrm{CFU} / \mathrm{ml}\right)$, and Ghilu et al. (2012) $\left(7.6 \log _{10} \mathrm{CFU} / \mathrm{ml}\right)$, but lower than the previous reports by Welearegay et al.(2012)(10.28 $\left.\log _{10} \mathrm{CFU} / \mathrm{ml}\right)$. The mean $\mathrm{CC}$ of raw milk in this study wasin agreement with findings of previous study by Welearegay et al. (2012) $\left(6.5 \log _{10} \mathrm{CFU} / \mathrm{ml}\right)$. However, the mean CC was higher than the reports of Yilma and Faye (2006) (5.41 $\left.\log _{10} \mathrm{CFU} / \mathrm{ml}\right)$,Nanuet al. (2007) (3.2 $\left.\log _{10} \mathrm{CFU} / \mathrm{ml}\right)$,Yilma (2012) (4.58 $\left.\log \mathrm{CFU} / \mathrm{ml}\right)$, and Dehinenet et al. (2013) (4.47 $\left.\log _{10} \mathrm{CFU} / \mathrm{ml}\right)$.

The overall mean coliform count (CC) of cow's milk in the study area was $\left(4.57 \log _{10} \mathrm{CFU} / \mathrm{ml}\right)$ and this finding was higher than acceptable value by American Public Health Association (1992) which is $\left(2.17 \log _{10}\right.$ $\mathrm{CFU} / \mathrm{ml}$ ). The coliform count obtained in the current study was comparable with that reported elsewhere in Ethiopiaby Godifay and Molla (2000) (4.84 $\left.\log _{10} \mathrm{CFU} / \mathrm{ml}\right)$, Alganesh et al. (2007) (4.46 $\left.\log _{10} \mathrm{CFU} / \mathrm{ml}\right)$, Derese (2008) (4.84 $\log _{10} \mathrm{CFU} / \mathrm{ml}$ ) from Bahir Dar, Tassew and Seifu (2011) (4.47 $\left.\log _{10} \mathrm{CFU} / \mathrm{ml}\right)$, Asaminew and Eyassu 
(2011) (4.49 $\left.\log _{10} \mathrm{CFU} / \mathrm{ml}\right)$, and Negash et al. (2012) (4.37 $\left.\log _{10} \mathrm{CFU} / \mathrm{ml}\right)$. This finding also agrees with the findings from East Africa Ombui et al. (1995) (4.68 $\left.\log _{10} \mathrm{CFU} / \mathrm{ml}\right)$ from Kenya. However, the mean CC of raw milk in this study was lower than the good number of previous reports in the country by Wubete (2004) $\left(6.1 \log _{10}\right.$ $\mathrm{CFU} / \mathrm{ml})$, Yilma and Faye (2006) $\left(6.56 \log _{10} \mathrm{CFU} / \mathrm{ml}\right)$ from central highlands of Ethiopia, Gemechu et al. (2014)(4.99 $\left.\log _{10} \mathrm{CFU} / \mathrm{ml}\right)$ from Shashemen town and Tadesse and Bacha(2012) (5.82 $\log _{10} \mathrm{CFU} / \mathrm{ml}$ )from Kersa District, Jimma Zone. But the mean CC of raw milk in this study was lower than the reports from other countries by Bonfoh (2003) from Mali, Rai and Dawvedi (1990) from India (5.89 $\log _{10} \mathrm{CFU} / \mathrm{ml}$ and $6.68 \log _{10} \mathrm{CFU} / \mathrm{ml}$ ), and Mosselet al. (1982) (5.8 $\left.\log _{10} \mathrm{CFU} / \mathrm{ml}\right)$ from Khartum. However, the coliform count obtained in the current study was higher than the report from the previous study done in different parts of Ethiopia byFekadu (1994) (3.8, 4.0 and $\left.3.8 \log _{10} \mathrm{CFU} / \mathrm{ml}\right)$, Abebe et al. (2012) $\left(4.03 \log _{10} \mathrm{CFU} / \mathrm{ml}\right)$, Mosu et al. (2013) $\left(1.82 \log _{10} \mathrm{CFU} / \mathrm{ml}\right)$, Mesfineet al. (2015) (1.24 $\left.\log _{10} \mathrm{CFU} / \mathrm{ml}\right)$. The higher coliform counts observed in this study in general, could be due to poor hygienic practices during production and subsequent handling, since they are mainly of fecal origin the initial contamination of the milk samples either from the milking cows (related with subclinical coliform mastitis, improper udder preparation, negligence on post-milking teat dipping and lack of herd health management), the milkers (improper hand washing, and fecal contamination), milk containers (improper cleaning with contaminated water and absence of detergents and/or disinfectants to wash), the milking environment (contamination from dust), and improper handling of milk (improperly washed or contaminated utensil for handling and storing milk).

The higher values found in this study for both TBC and CC as compared to the previous reports and EU and USA standards were attributed to the cumulative results of milk contamination at different levels while milk was passing through the different sampling points. Factors that could potentially contribute to the contamination of milk in this study include, poor pre-milking udder preparation, insufficient cleaning of milkers' hands, milking utensils and storage containers, lack of potable water for washing purpose, storage and transport time after the milk leaves the dairy farms, and handling of milk by different plastic containers may cause the contamination of milk higher, since the increased use of plastic containers also increased the chance of contamination as most plastic containers have characteristics that make them unsuitable for milk handling. Because plastics containers are easily scrape or cut and provide suitable or hiding places for bacteria during cleaning and sanitization and they are poor conductor of heat that will hinder effective sanitization by heat (Godefay and Molla, 2000). Milk produced under hygienic conditions from healthy cows should not contain more than $10^{5} \mathrm{CFU} / \mathrm{ml}$ for TBC and $1.50 \times 10^{2} \mathrm{CFU} / \mathrm{ml}$ for $\mathrm{CC}\left(\mathrm{O}^{\prime}\right.$ Connor, 1994). The presence of high numbers of coliforms in milk also indicates that the milk has been contaminated with fecal materials, unclean udder and teats of cows, use of improperly washed milking equipment, poor hygiene of the milking environments, unsanitary milking practices, contaminated water and cows with subclinical or clinical coliform mastitis can all lead to elevated coliform count in raw milk (Jayarao et al.,2004).

In this study, udder milk had better bacteriological quality relatively when comparing with other sampling points, because it was not subjected to further contamination after milking. The continuous contamination of raw milk as the milk passed through different points was evidenced by statistically significant increment of both counts of TBC and $\mathrm{CC}$ from the initial point of milk production to selling point. The first contamination occurred during milking due to insufficient udder preparations, followed by contaminations from milking bucket and milkers' hand at farm level. In addition, contamination of milk occurred as the milk was transported to the milk collection centers and handled at the milk collection centers due to lack of cold chain, use of milk containers lacking tight sealing, handling of milk with unclean hands and equipment. Further contamination occurred as milk was transported to the selling point without any cold chain facility for long time elapsed, high exposure to dusts and pathogenic organisms from the environment and lack of refrigeration facility throughout the critical point (O'Connor, 1995; Godefay and Molla, 2000).

The mean total bacterial counts of the samples collected during the first sampling period at udder level were significantly different from the counts of the samples collected during the third sampling period (Table 8). Also the mean TBC of the samples collected during first sampling period significantly $(p<0.05)$ differed from the counts of the samples collected from collection center during the third sampling period. The seasonal value indicated that temperature of the environment also matters in the microbial quality of milk. It was observed that the load or mean of bacterial counts were high in raw milk in all sampling periods (seasons) when compared with legal acceptable limits set (EU). The high microbial load indicated poor udder health of the cows and the unhygienic practices prevailing at the production level. Proceeding time and environmental condition during transportation plus unhygienic practices in milking process allows favorable growth of microorganism increasing microbial load.

The results of screening for mastitis using CMT indicated that $92 \%$ of the samples were positive for mastitis. Mastitis infection might have contributed a lot to the many bacterial species isolated and high bacterial counts of milk samples found in this study. This may render milk unsuitable for human consumption and this poses an impact on economy and human healthy (Radostitis et al., 2007). An increasing in cell counts (SCC) is indicative of increased inflammation and has a negative influence on the quality of raw milk. If mastitis is with no visible sign, it is termed as subclinical mastitis (SCM). The SCM is always related to low milk production, changes to milk 
consistency (density), reduced possibility of adequate milk processing, low protein and high risk for milk hygiene since it may even contain pathogenic organisms (Sharma et al., 2011). Milk from dairy animals infected with mastitis generally has higher total bacteria counts and somatic cell counts than milk from uninfected animals. In generally the contribution of mastiticudder in the bacterial quality of cow's milk is an established fact and therefore, adequate control of mastitis (udder health programs at a herd level) could help to enhance the production of high quality dairy products (Bhutto et al., 2010; Mekbib et al., 2010).

Poor hygiene, practiced by handlers of milk and milk products, may lead to the introduction of pathogenic micro-organisms into the milk products and if there is further processing before consumption, these foods may pose risk to the consumers. Therefore, provision of milk and milk products of good hygienic quality is desirable from consumer health point of view (Yilma, 2010).According to Yilma and Faye (2006) the first step to set a high quality product with longer shelf life is to make sure that the production and handling is hygienic, which will result in fewer spoilage organisms in the products.

\section{Conclusion and recommendations}

Clean milk could only be obtained if effective sanitary measures are taken starting from the point of milk withdrawn from the cow until it reaches the consumers. The results obtained in this study showed that milk available to consumer in Jimma town has poor quality. Measurable increased in total bacterial counts and coliform counts throughout all sampling points were indicated. The major factors that contributed to poor quality of milk in the study area were poor hygienic standard, insufficient cleaning of milkers hand and milking equipment, use of poor quality (well water) for cleaning of udder, milking utensils and storage containers, absence of cold chains facility and handling of milk by plastic containers. Furthermore, the result showed that the milk samples collected from farms, collection centers and vendors were subjected to microbial contamination. High bacterial loads, the presence of several pathogenic bacteria in milk samples not only affect the milk quality but also definitely pose a safety issue to consumer. The difference between TBC and coliform counts and bacterial isolates at different sampling points clearly demonstrated exogenous sources of milk bacterial contamination. The current study indicated majority of raw milk samples from the udder, bucket and all the samples from storage containers and vendors had higher bacterial counts and coliform counts which was above acceptable limit set by American and European community member states (EU). The somatic cell counts (SCC) of bulk milk samples from almost all farms had higher cell counts than acceptable limit suggesting the prevalence of subclinical mastitis..

Based on the above conclusion the following recommendations are forwarded:

- Awareness should be created along dairy cow owners, collection centers and vendors on the importance of good hygienic milk production to reduce the level of bacterial contamination using the available limited resource.

- There is need to create farmers awareness to improve their efforts in preventing and controlling mastitis.

- The use of locally available milk cooling system at all milk handling points is essential to improve the quality of milk.

- Providing milk cooling system at affordable prices is required at least at the collection centers and at vendors.

\section{ACKNOWLEDGEMENTS}

I would like to express my heartfelt thanks and appreciation to my academic advisor Prof. Tadele Tolosa and coadvisor Dr. Benti Deresa for their unreserved intellectual guidance, suggestions and paper correction which was very much exacting and invaluable.

I also would like to thank the Mastitis and milk quality laboratory of Jimma University College of Agriculture and Veterinary Medicine for their permission to use the laboratory facilities for my research work.

This thesis was undertaken using the research grant allocated by College of Agriculture and Veterinary Medicine, Jimma University. I am grateful to the university in particular, and government of Ethiopia, in general, for providing me the research fund. Konta Special Woreda Administration and Agricultural development office of, Southern Nations, Nationalities and Peoples' Regional State are also highly acknowledged for sponsoring me to attend this postgraduate programme and financial support throughout the study period.

\section{References}

AbdElrahman, M. A., Said Ahmad, A. M. M., Ibtisam, E. M. El Zubeir, E. L., and Ahmed, M. K. A. (2009): Microbiological and physiochemical properties of raw milk used for processing pasteurized milk in Blue Nile Dairy Company (Sudan). J. Basic and Applied. Sci., 3 (4):3433-3437.

Abebe, M., Daniel, A., Yimtubezinash, W. and Genene, T. (2013): Identification and antimicrobial susceptibility of Staphylococcus aureusisolated from milk samples of dairy cows and nasal swabs of farm workers in selected dairy farms around Addis Ababa, Ethiopia.acade. J., 7 (27), Pp.3501-3510.

Abebe, M., Hailelule, A.,Abrha, B., Nigus, A., Birhanu, M., Adane, H., Genene, T., Daniel, H. Getachew, G., 
Merga, G., and Haftay, A. (2014): Antibiogram of Escherichia coli strains isolated fromfood of bovine origin in selected Woredas of Tigray,Ethiopia. J. Bacteriol. Res.,6 (3), Pp. 17-22.

Aberra, A. (2010): Microbiological safety of pasteurized and raw milk from milk processing plants in and around Addis Ababa, M.Sc. thesis. Addis Ababa University, Ethiopia. Pp. 89-91.

Addis, M., Mahindra P., and Kyule, N. (2011): Isolation and Identification of Staphylococcus Species from Raw Bovine Milk in DebreZeit, Ethiopia. Medwell. Vet. Res., 4 (2): 45-49.

Addis, M., Workineh, S., Bayleyegne, M., Moges, A., and Tadele, K. (2005): Antimicrobial susceptibility profile of mastitis isolates from cows in three major Ethiopian Dairies. Rev. Med. Vet., 176:391-394.

Alemu, A., Abebe, G., Tsegaye, W., and Golassa, L. (2011): Climatic variables and malaria transmission dynamics in Jimma town, South West Ethiopia. Parasit.Vector., 4: 30.

Alganesh, T. Ofodile, L. N., and Fikadu, B. (2007): Microbial quality and chemical composition of raw whole milk from Horro cattle in East Wollega, Ethiopia. Available on: www.ajol.info/index.php/ejesc/article/View/41995.

Alganesh, T. Ofodile, L. N., and Fikadu, B. (2007): Microbial quality and chemical composition of raw whole milk from Horro cattle in East Wollega, Ethiopia. Available on: www.ajol.info/index.php/ejesc/article/View/41995

Al-Tahiri, R. (2005): A comparison on microbial conditions between traditional dairy products sold in Karak and same products produced by modern dairies. Pak. J. Nutri., 4 (5): 345-348

American public health association (APHA) (1992): Standard Method for the Examination of Dairy products, 16th edition, APHA, Washington. Pp. 213-220

Asaminew, T, and Eyassu, S. (2011): Microbial quality of raw cow's milk collected from farmers and dairy cooperatives in Bahir Dar Zuria and Mecha district, Ethiopia. Agriculture.and Biology. J. North. Ameri., 2 (1), Pp. 29-33.

Aseffa, A. (2010): The microbiological safety of pasteurized and raw milk form milk processing plants in and around Addis Ababa. Addis Ababa, Ethiopia.

Ashenafi, M. and Beyene, F. (1994): Microbial load, microflora, and keeping quality of raw and pasteurized milk from a dairy Farm. Bull. Anim. Hlth. Prod. Afr., 42:55-59.

Asrat, A. (2010): Production, Utilization and Marketing of Milk and Milk Products Quality of Fresh Whole Milk Produced in and Around Boditti Town Wolayta Zone, M.Sc. Thesis.

Bedada, B. A., and Hiko, A. (2011): Mastitis and antimicrobial susceptibility test at Asella, Oromia Regional state, Ethiopia. J. Microbiol. Antimic.,3: 228-232.

Befekadu, D., and Birhanu, N. (2000): Annual Report on the Ethiopian Economy: Volume 1, 1999/2000. The Ethiopian Economics Association, Addis Ababa, Ethiopia, Pp. 429.

Bhutto, A.L., Murray, R.D., and Woldehiwet, Z. (2010): Udder shape and teat end lesions as potential risk factors for high somatic cell counts and intra-mammary infections in dairy cows. Vet. J.,183: 63-67

Biruk, H., Samson, W., and Yilma, Z. (2009): Microbial properties of milk and traditionally produced Ethiopian fermented milk products: a review. Proceedings of the 17th Annual conference of the Ethiopian Society of Animal Production (ESAP) held in Addis Ababa, Ethiopia, September 24 to 26. Pp. 137-148.

Bukuku, J. N. (2013): Awareness of health risks as a result of consumption of raw milk in Arusha City and Meru District, Tanzania. Unpublished dissertation for award of MSc. degree at Sokoine University of Agriculture, Morogoro, Tanzania. Pp. 1-89.by different sources. Indian dairy man, 42,520-523.

Chambers, J. V. (2002): The microbiology of raw milk. In: Dairy Microbiology Handbook, 3rd edn (ed. R.K. Robinson), John Wiley and Sons, New York. Pp 39-90.

Clinical and Laboratory Standards Institute (CLSI) (2007): Performance standards for antimicrobial susceptibility testing: 17th informational supplement. CLSI document M100-S17. (ISBN 1-56238-625-5): Clinical and Laboratory Standards Institute, 940 West Valley Road, suite 1400, Wayne, Pennsylvania 19087-1898 USA. Cooperative Extension, Institute of Agriculture and Natural Resources, University Of Nebraska-Lincoln.G931151-A, Pp. 1-5.

Daka, D., G/silassie, S., and Yihdego, D. (2012): Antibiotic-resistance Staphylococcus aureusisolated from cow's milk in the Hawassa area, South Ethiopia. Annal.Clin.Microbio and Antimicro.,11: 26.

Debebe, W. (2010): Physicochemical Properties and Safety of Street-vended Milk in and Around Addis Ababa City (Kotebe, Bishoftu and Chancho), M.Sc. Thesis. Haramaya University, Ethiopia.

Debrezeit, Faculty of Veterinary medicine, Addis Ababa University, MSc Thesis

DeGraaf, T., Romero Zuniga, J. J., Cabalellero, M., and Dwinger, R. H. (1997): Microbiological quality aspects of cowees milk at a smallholder cooperative in Turrialba, Costa Rica. Revue Elev. Med. Vet. Pays Trop., 50 (1): $57-64$

Dehinenet, G., Mekonnen,H., Ashenafi, M. and Emmanuelle, G. (2013). Determinants of raw milk quality under a smallholder production system in selected areas of Amhara and Oromia National Regional States, Ethiopia.Agric. Biol. J. N. Am., 4 (1): 84-90. 
DeLaval International AB. (2004): DeLaval Cell Counter DCCTM. Stockholm, Sweden

Derese, T. (2008): Present situation of urban and peri-urban milk production and quality of raw milk produced in west Shoa zone, Oromia Region, Ethiopia. M.Sc. Thesis Haramaya University, Ethiopia

Eshetu, T. (2008): The role of dairy cooperatives in stimulating Innovation and market oriented smallholdersDevelopment: the case of ada'a dairy cooperative, Central Ethiopia.School of Graduate Studies Haramaya University.M.Sc thesis.

Esther, N. N., Collision, E. k., Gashe, B.A. and Mpuchane, S. (2004): Microbiological quality of milk from two processing plants in Gaborone, Botswana. Food control.15: 181-186.

Fatine, H., Abdelmoula, E., Doha, B. and Hinde, H. (2012): Bacterial Quality of Informally Marketed Raw Milk in Kenitra City, Morocco. Paki. J. Nutri., 11(8): 662-669.

Fekadu, B. (1994): Present situation and Future Aspect of Milk production, Milk handling and Processing of Dairy products in Southern Ethiopia. Farm made milk products in Southern Ethiopia: 1.Chemical and Microbial quality. Ph.D. Thesis. Depart. Food.Sci, Agricul. U. Norway., Pp1-11.

Galton D. M., Petersson L. G. and Merril W. G. (1986): Effects Of Pre Milking Udder Preparation Practices On Bacterial Counts In Milk And On Teats. J. Dairy. Sci., 69: 260-266.

Garedew, L, Berhanu, A., Mengesha, D., and Tsegay, G. (2012): Identification of gram-negative bacteria from critical control points of raw and pasteurized cow milk consumed at Gondar town and its suburbs, Ethiopia. BMC Publ.Hlth.,12: 950.

Gemechu, T., Beyene, F., and Eshetu, M. (2014):Handling Practices and Microbial Quality of Raw Cow's Milk Produced and Marketed in Shashemene Town, Southern Ethiopia.Int. J. Agricu. and Soil. Sci. (ISSN: 23159989), 2(9) Pp. 153-162.

Ghilu, S., Yilma, Z. and Banerjee, S. (2012): Assessment of Quality and Marketing of Milk and Milk Products in the Central Highlands of Ethiopia. LAP LAMBERT Academic Publishing

Godefay, B., and Molla, B. (2000): Bacteriological quality of raw cow's milk from four dairy farms and milk collection center in and around Addis Ababa. Berl.Münch.Tierärztl.Wschr.,113 (7-8): 276-278.

Gonfa, A., Howard, A. F., and Wilhelm, H. (2001): Field survey and literature review on traditional fermented milk products of Ethiopia. Int. J. Food. Microbiol.,68: 173-186.

Hamid, O. and Owni, O. (2007): Microbiological properties and sensory characteristics of white cheese collected in Zalingei area, West Darfur State. J. Ani and Vet. Sci., 2: 61-65.

Hillerton, J. E., and Berry, E. A. (2004): Quality of the milk supply: European regulations versus practice. Proceedings 43rd NMCAnnual Meeting.Pp. 207-214.

Jayarao, B. M., Pillai, S. R., and Wolfgang, D. R. (2001): Herd level information and bulk tank milk analysis tools for improving milk quality and herd udder health. Bov.Pract.35: 23-35.

Jorgensen, H. J., Mork, T., Caugant, D. A., Kearns, A., and Rørvik, L. M. (2005): Genetic Variation among Staphylococcus aureus Strains from Norwegian Bulk Milk. App and Environ. Microbiol.,71: 8352-8361

Kaloreu, D., Shanmugam, Y., Kurkure, N., Chousalkar, K. and Barbuddhe, S. (2007): PCRbased detection of genes encoding virulence determinants in Staphylococcus aureusfrom bovine sub clinical mastitis cases. $J$. Vet. Sc., 8: 151-154.

Kivaria, F. M., Noordhuizen, J.P.T.M. and Kapaga, A. M. (2006a): Evaluation of the hygienic quality and associated public health hazards of raw milk marketed by smallholder dairy producers in the Dar es Salaam region, Tanzania. Tropi. Anim. Hlth. Produ.,38: 185-194..

Makokha, S. and Fadiga, M. L. (2009): Exploiting markets for dairy and meat products' quality and safety: A Kenyan case study. Research report 24 on Demand for livestock products in developing countries with a focus on quality and safety attributes: Evidence from Asia and Africa.

Mekibib, B., Furgasa, M., Abunna, F., Megersa, B., and Regassa, A. (2010): Bovine Mastitis: Prevalence, Risk Factors and Major Pathogens in Dairy Farms of Holeta Town, Central Ethiopia. Vet. World.,3 (9), Pp. 397 403.

Mesfine, S. Feyera, T. and Mohammed, O. (2015):Microbiological Quality of Raw Cow's Milk from Four Dairy Farms in Dire Dawa City, Eastern Ethiopia.World. J. Dairy and Food Sci., 10 (1): 09-14.

Mohamed, A., Ahmed, M., Simeon, E. and Yemesrach A. (2004): Dairy Development In Ethiopia. EPTD Discussion Paper No. 123. International Food Policy Research Institute, Washington, DC 20006 U.S.A.

Mossel, D. R., Ryoba, R., and Karimuribo, E. (1982): Prevalence of clinical and sub clinical mastitis and quality of milk on small holder dairy farms in Tanzania. J. SouthAfri. vet. Assoc.Moroporo.Tanazania.,80: 163-168.

Mosu, S., Megersa, M., Muhie, Y., Gebremedin, D., and Keskes, S. (2013): Bacteriological quality of bovine raw milk at selected dairy farms in DebreZeit town, Ethiopia. J. Food. Sci and Techno. Res.,1 (1), Pp. 1-8

Nanu, E.; Latha, C.; Sunil, B.; Prejit, T. M. and Venon, K.V. (2007): Quality assurance and public health safety of raw milk at the production point. Ameri. J. Food. Techno.,2: 145-152.

National Mastitis Council (NMC) (1999): Laboratory Handbook on Bovine Mastitis. National Mastitis Council Inc., Madison, WI, Pp 22. 
O’Connor, C. (1995): Rural dairy technology; ILRI training manual 1, ILRI (International Livestock Research Institute). Addis Ababa, Ethiopia, Pp.12.

O’Connor, C.B. (1994):Rural Dairy Technology. International Livestock Research Institute (ILRI) Training manual 1. International Livestock Research Institute Addis Ababa, Ethiopia. Pp.133.of milk from two processing plants in Gaborone, Botswana. Food control.15: 181-186.

Oliver, S. P., Boor, K.J., Murphy, S. C., and Murinda, S. E. (2009): Food safety hazards associated with consumption of raw milk. Foodbon.Pathog. D., 6 (7):793-806.

Ombui, J. N., Arimi, S. M., Mcdermott, J. J., Mbugua, S. K., Githua, A.A., and Muthoni, J. (1995): Quality of raw milk collected and marketed by dairy cooperative societies in Kiambu District, Kenya. Bull. Anim. Hlth. Prod. Afr., 43: 277-284.

Pandey, G. S. and Voskuil, G. C. S. (2011): Manual on Milk safety, quality and hygiene. Golden Valley agricultural Research Trust, Zambia.Pp. 52.

Parekh, T. S. and Subhash, R. (2008): Molecular and bacteriological examination of milk from different milch animals with special reference to Coliforms. Curr.Res.Bacterio.,1(2):56-63.

Park, Y. W. (2009):Bioactive components in milk and dairy products. First edition. Wiley- Blackwell publishers

Quinn, P. J., Carter, M. E., Markey, B. and Carter, G. R. (1999): Clinical Veterinary Microbiology. Mosby International Limited, Spain, Pp. 118-143, 209-242.

Radostits, O. M., Gay, C. C., Hinchchiff, K.W., and Constable, P. D. (2007): A Text book of the Disease of cattle, sheep, pigs and goats. 10th ed. London: Ballieer, Tindall.

Rai, C. K. and Dawivedi, H.B. (1990): Bacteriological quality of milk supplied in kanapurcity

Reda, M., Taddele, H., Afera, B. and Bsrat, A. (2014):Bacteriological Quality Assessment of Milk in Dairy Farms, Cafeterias and Wholesalers in Adigrat, Tigray, Ethiopia.Faculty of Veterinary Medicine, Addis Ababa University, DVM Thesis.

Ruegg, P. (2003): Practical food safety interventions for dairy production. J. Dairy. Sci. 86 (1): E1-E9

Sharma, D., Sharma, P. K. and Malik, A. (2011): Prevalence and antimicrobial susceptibility of drug resistant staphylococcus aureusin raw milk of dairy cattle. Int. Res. J. Microbio., 2 (11): 466-470.

Shija, F. (2013): Assessment of milk handling practices and bacterial contaminations along the dairy value chain in Lushoto and Handeni districts in Tanga region. Unpublished dissertation for award of MSc. degree at Sokoine University of Agriculture, Morogoro, Tanzania.Pp 1-88.

Soomro, A. H., Arain, M. A., Khaskheli, M. and Bhuto, B. (2002): Isolation of E. coli from raw milk and milk products in relation to public health sold under market conditions at Tandonjam Pakistan. J. food.Nutri.,1 (3): 151-152.

Sophia, D. (2011): Microbiological Quality of Milk Produced in Urban and Peri-Urban Farms in Central Ethiopia and its Public Health Impact, Ohio State University, Pp. 97.

SPSS (2010): Statistical Package for Social Science, Inc. SPSS for window (Version 16). SPSS BI Survey Tips. Inc. Chicago, USA

Stulova, I., Adamberg, S., Kriščiunaite, T., Kampura, M., Blank,L., and Laht, T. M. (2010): Microbiological quality of raw milk produced in Estonia. Microbio.,1: 683-690.

Tadess, T and Bacha, K. (2014): Microbiological Quality and Safety of Raw Milk Collected fromKersa District, Jimma Zone, South west Ethiopia.

Tassew, A. and E. Seifu, (2011): Microbial quality of raw cow's milk collected from farmers and dairy cooperatives in Bahir Dar Zuria and Mecha district, Ethiopia. Agric. Biol. J. N. Am., 2(1): 29-33

Tolosa, T., Verbeke, J., Piepers, S., Supré, K., and De Vliegher, S. (2013):Risk factors associated with subclinical mastitis as detectedby California Mastitis Test in smallholder dairy farms in Jimma, Ethiopia using multilevel modeling. Preve.Vet. Medi., Pp.68-75.

Welearegay, H. Yilma, Z. and Yosef, T. (2012):Hygienic practices and microbiological quality of raw milk produced under different farm size in Hawassa, southern Ethiopia. 1 (4), Pp. 132-142.

Wubete, A. (2004): Bacteriological quality of bovine milk in small holder dairy farms in Debrezeit, Faculty of Veterinary medicine, Addis Ababa University, MSc Thesis.

Yigrem, S, and Welearegay, H. (2015): Assessment of Microbial Quality and Safety of Traditional Fermented Milk-'Irgo', Collected from Hawassa City, South Ethiopia. J Food Proce. Technol. 6 (3): 431.

Yilma Z (2010). Microbial Properties of Ethiopian Marketed Milk and Milk Products and Associated Critical Points of Contamination: An Epidemiological Perspective, Addis Ababa, Ethiopia. pp. 298- 322.

Yilma, Z. (2003): Sanitary conditions and microbial qualities of dairy products in urban and periurban dairy shed of the central Ethiopia. DEA. Lyon, France.

Yilma, Z. (2012): Microbial Properties of Ethiopian Marketed Milk and Milk Products and Associated Critical Points of Contamination: An Epidemiological Perspective

Yilma, Z., and Faye, B. (2006): Handling and Microbial Load of Cow's Milk and IrgoFermented Milk Collected from Different Shops and Producers in Central Highlands of Ethiopia. Eth. J. Anim. Prod., 6 (2): 67-82. 
Yilma, Z., and Faye, B. (2006): Handling and Microbial Load of Cow's Milk and IrgoFermented Milk Collected from Different Shops and Producers in Central Highlands of Ethiopia. Eth. J. Anim. Prod., 6 (2): 67-82.

\section{List of abbreviations}

$\begin{array}{ll}\text { ANOVA } & \text { Analysis of variance } \\ \text { APHA } & \text { American public health association } \\ \text { CC } & \text { Coliform count } \\ \text { CFU/ml } & \text { Colony forming unit per ml } \\ \text { CLSI } & \text { Clinical and Laboratory Standards Institute } \\ \text { CMT } & \text { Californian mastitis test } \\ \text { CNS } & \text { Coagulase negative Staphylococcus } \\ \text { CSA } & \text { Central statistics authority } \\ \text { DCC } & \text { DeLaval cell counter } \\ \text { LBC } & \text { Laboratory pasteurized count } \\ \text { Log } 10 & \text { Logarism in base ten } \\ \text { MDR } & \text { Multi-drug Resistant } \\ \text { MHA } & \text { Mueller- Hinton Agar } \\ \text { MRSA } & \text { Methicillin resistant Staphylococcus aureus } \\ \text { MSA } & \text { Mannitol Salt Agar } \\ \text { PCA } & \text { Plate count agar } \\ \text { pH } & \text { Power of Hydrogen } \\ \text { PIC } & \text { Preliminary incubation count } \\ \text { SCC } & \text { Somatic cell count } \\ \text { SEs } & \text { Staphylococcal Enterotoxins } \\ \text { SFP } & \text { Staphylococcal food poisoning } \\ \text { SPC } & \text { Standard plate count } \\ \text { Spp } & \text { Species } \\ \text { SPSS } & \text { Statistical Package for Social Sciences } \\ \text { TBC } & \text { Total bacterial count } \\ \text { U.S } & \text { United State of America } \\ \text { USAID } & \text { United States Agency for International Development } \\ \text { VRBA } & \text { Violet Red Bile Agar } \\ \text { WHO } & \text { World Health Organization } \\ & \end{array}$

